\title{
Biological Therapies in Children and Adolescents with Severe Uncontrolled Asthma: A Practical Review
}

\author{
Martina Votto ${ }^{1,2, *}$ \\ Maria De Filippo ${ }^{1,2, *}$ \\ Amelia Licari (iD) ${ }^{1,2}$ \\ Alessia Marseglia ${ }^{2}$ \\ Mara De Amici ${ }^{3}$ \\ Gian Luigi Marseglia (D) ${ }^{1,2}$ \\ 'Pediatric Clinic, Fondazione IRCCS \\ Policlinico San Matteo, Pavia, Italy; \\ ${ }^{2}$ Department of Clinical, Surgical, \\ Diagnostic and Pediatric Sciences, \\ University of Pavia, Pavia, Italy; ${ }^{3}$ Immuno- \\ Allergology Laboratory, Clinical \\ Chemistry Unit, Fondazione IRCCS \\ Policlinico San Matteo, Pavia, Italy
}

*These authors contributed equally to this work
Correspondence: Amelia Licari

Pediatric Clinic, Fondazione IRCCS

Policlinico San Matteo, p.le C. Golgi n.19,

Pavia, 27100, Italy

Tel/Fax +390382502629

Email amelia.licari@unipv.it

\begin{abstract}
Severe uncontrolled asthma is a complex and heterogeneous disease. A multidisciplinary assessment is required to correctly identify and manage children and adolescents with severe asthma because they may require strict monitoring and additional treatment with advanced targeted therapies. Recent research efforts have focused on identifying epidemiologic, clinical, and molecular mechanisms that underlie severe asthma, leading to the recognition of different phenotypes and endotypes and identifying biomarkers able to predict the response to biologic therapies. Additional progress has occurred by introducing biological therapies that have revolutionized the care of chronic allergic diseases in the adult and pediatric population. In this review, we briefly summarized the current literature on biological therapies to treat severe asthma in children and adolescents.
\end{abstract}

Keywords: severe asthma, children, adolescents, biological therapy, endotype, phenotype

\section{Introduction}

Atopic diseases are multifactorial disorders resulting from the interactions of genetic predisposition, impaired immune response, environmental and lifestyle risk factors, influencing disease onset, clinical expressivity, and variability of illness severity. ${ }^{1,2}$ Allergic diseases showed a remarkably increased prevalence in the last decades. ${ }^{1,2}$ The global health burden of severe allergic diseases is relevant since patients may experience disability, anxiety and emotional distress, social restrictions, and reduced quality of life (QoL). ${ }^{3-6}$ Despite some progress made in understanding the pathogenesis of atopic diseases, significant differences in clinical characteristics, treatment response, and natural history have been described in many allergic patients treated with conventional therapies. To date, studies that aim to identify potential cellular and molecular signature (endotypes) have given rise to new targeted and specific treatment strategies for precision medicine and individualized therapies in allergic disorders. ${ }^{7,8}$

In this brief review, we summarize current evidence on available biological therapies to treat severe asthma phenotypes in children and adolescents.

\section{Severe Asthma in Pediatrics}

Severe asthma is a chronic airway disease characterized by respiratory symptoms that affects about $0.23-0.5 \%$ of children and adolescents. ${ }^{9}$ Pediatric patients with severe uncontrolled asthma generally show a reduced QoL due to troublesome persistent 
respiratory symptoms, neuropsychological issues, missed school days, recurrent life-threatening asthma attacks, and side effects of systemic corticosteroids. ${ }^{10,11}$ According to current guidelines, severe asthma is defined by persistent/ recurrent asthmatic symptoms or acute asthma attacks despite high doses of inhaled and/or oral corticosteroids (OCS) (Table 1). ${ }^{12-14}$ Diagnosis of severe uncontrolled asthma requires a multidisciplinary assessment and the exclusion of asthma-mimicking conditions (Table 2). ${ }^{15}$ After evaluating comorbidities (sinus disease, gastroesophageal reflux, obesity, anxiety, and depression) and modifiable treatment-related issues (non-adherence to medication, improper inhalation technique, persistent adverse environmental exposures, and emotional factors), additional biologic therapies may be prescribed in children and adolescents with uncontrolled asthma. ${ }^{16-18}$

Severe pediatric asthma is a highly heterogeneous disease with multiple phenotypes. ${ }^{9,11}$ Several research efforts have been addressed to identify clinical phenotypes of severe pediatric asthma in the last years. Compared to adult-onset, early-onset asthma is usually characterized by high levels of total serum immunoglobulin E (IgE), blood eosinophilia, and aeroallergen polysensitization. However, a small group of pediatric patients showed a reduction in their lung function and small airway hyperresponsiveness. ${ }^{19-21}$ Several studies on cluster analyses have been realized to classify
Table 2 Differential Diagnosis of Severe Uncontrolled Asthma

\begin{tabular}{|l|l|}
\hline Toddlers & \multicolumn{1}{|c|}{ Children and Adolescents } \\
\hline Tracheobronchomalacia & Vocal cord dysfunction \\
Bronchopulmonary Dysplasia & Hyperventilation \\
Tuberculosis & Exercise-induced hyperventilation \\
Cystic Fibrosis & \\
Primary Ciliary Dyskinesia & \\
Obliterative bronchiolitis & \\
Immunodeficiencies & \\
Foreign body & \\
Vascular rings & \\
\hline
\end{tabular}

children with severe asthma into subgroups with shared clinical features. $^{22}$ Childhood severe asthma subgroups are mainly represented by sex, multiple allergic sensitization and comorbidities, degree of airway obstruction, rates of exacerbation, age of asthma onset ( $>15$ years), body mass index, the dose of OCS, and nasal symptoms. $^{22}$

The clinical classification of asthma cannot predict the response to advanced therapies, such as biologics. Therefore, current research shifted from the phenotype evaluation towards identifying cellular and molecular mechanisms (endotypes) and related biomarkers of severe asthma that could predict the response to therapies and assist in designing personalized therapies. $^{8,23}$

Table I Definitions of Severe Uncontrolled Asthma

\begin{tabular}{|c|c|c|c|c|}
\hline Guidelines & Definitions & $\begin{array}{l}\text { High } \\
\text { Dose } \\
\text { Therapy }\end{array}$ & $\begin{array}{c}\text { Poor } \\
\text { Control }\end{array}$ & Exacerbations \\
\hline $\begin{array}{l}\text { European Respiratory Society/ } \\
\text { American Thoracic Society (ERS/ } \\
\text { ATS) } 2020^{12}\end{array}$ & $\begin{array}{l}\text { Asthma that requires treatment with high dose inhaled } \\
\text { corticosteroids plus a second controller (and/or systemic } \\
\text { corticosteroids) to prevent it from becoming 'uncontrolled' or } \\
\text { which remains 'uncontrolled' despite this therapy. }\end{array}$ & Yes & Yes & No \\
\hline $\begin{array}{l}\text { Global Initiative for the } \\
\text { treatment of Asthma (GINA) } \\
2020^{13}\end{array}$ & $\begin{array}{l}\text { Asthma that requires GINA Step } 4 \text { or } 5 \text { treatment or such } \\
\text { treatment to maintain good symptom control and reduce } \\
\text { exacerbations ( } \geq 2 / \text { year or } \geq 1 \text { /year requiring hospitalization). } \\
\text { Asthma is uncontrolled despite adherence with maximal } \\
\text { optimized Step } 4 \text { or Step } 5 \text { therapy and treatment of contributory } \\
\text { factors, or that worsens when high dose treatment is decreased. }\end{array}$ & Yes & Yes & Yes \\
\hline $\begin{array}{l}\text { British Thorac Society (BTS) } \\
2016^{14}\end{array}$ & $\begin{array}{l}\text { A prior diagnosis of asthma exists, and asthma-like symptoms and } \\
\text { asthma attacks persist, despite prescription of high-dose asthma } \\
\text { therapy (medium-dose ICS plus a LABA or LTRA; low-dose ICS } \\
\text { plus a LABA or LTRA and an appropriate additional therapy; or } \\
\text { continuous or frequent use of oral steroids). }\end{array}$ & Yes & Yes & Yes \\
\hline
\end{tabular}

Abbreviations: ICS, inhaled corticosteroid; LABA, long-acting $\beta 2$-agonist; LTRA, leukotriene receptor antagonists. 
To date, two main endotypes of severe asthma have been proposed based on the type of airway inflammation: type 2 (T2)-high and T2-low asthma endotypes. ${ }^{8}$ The pathogenetic mechanisms of the T2-high endotype are driven by IgE and specific cytokines. Innate and adaptive immune cells release interleukin (IL)-4, IL-5, and IL-13 that are the pivotal mediators of type 2 inflammation. ${ }^{24}$ The T2-high endotype is the most common in childhood, and clinically matches with the early onset asthma phenotype; in fact, this endotype generally shows an airway eosinophilic inflammation and multiple allergic sensitizations. On the other hand, the neutrophilic or paucigranulocytic airway inflammation characterizes the T2low asthma endotype, which is less common in childhood. ${ }^{25,26}$ In particular, the T2-low inflammation is mainly sustained by IL-8, IL-17, IL-22, other T cell-related cytokines, and epithelial cell-derived cytokine. ${ }^{25,26}$

In the last years, more complete asthma pathogenesis efforts have allowed the emergence and the clinical application of new biological therapies, mainly targeting type 2 inflammation. ${ }^{27,28}$

\section{Omalizumab}

\section{Mechanism of Action and Dosage}

The pharmacological blockade of IgE was the first successful strategy for severe asthma. Thus, omalizumab was the first humanized monoclonal anti-IgE with a pediatric indication (Table 3) ${ }^{29,30}$ By binding to circulating IgE, omalizumab directly prevents their interaction with the IgE receptor ( $\mathrm{FC} \varepsilon \mathrm{R} 1)$ on the mast cells and basophil surface, inhibiting the release of pro-inflammatory mediators. ${ }^{31}$ Besides, omalizumab indirectly downregulates the expression of $\mathrm{FC} \varepsilon \mathrm{R} 1{ }^{31}$

Omalizumab is recommended as an additional therapy for children (age $\geq$ six years) with allergic asthma showing elevated serum IgEs $(>30$ and $<1500 \mathrm{IU} / \mathrm{mL})$ and positive sensitization to one or more perennial aeroallergens. ${ }^{15}$ The

Table 3 Sum of Biological Therapies for Severe Asthma Management in Pediatrics

\begin{tabular}{|c|c|c|c|c|c|c|}
\hline $\begin{array}{l}\text { Biological } \\
\text { Therapy }\end{array}$ & $\begin{array}{l}\text { Mechanism } \\
\text { of Action }\end{array}$ & Indication & Population & Dosage & $\begin{array}{c}\text { Criteria of Response } \\
\text { to Therapy }\end{array}$ & $\begin{array}{l}\text { Common Side } \\
\text { Effects }\end{array}$ \\
\hline Omalizumab & Anti-lgE & $\begin{array}{l}\text { Add-on treatment } \\
\text { of severe allergic } \\
\text { asthma with } \\
\text { elevated IgE and } \\
\text { positive specific IgE } \\
\text { at least one } \\
\text { aeroallergen. }\end{array}$ & $\begin{array}{l}\text { Children } \\
\geq 6 \text { years, } \\
\text { adolescents } \\
\text { and adults }\end{array}$ & $\begin{array}{l}\text { SC injection every } 2 \text { or } \\
4 \text { weeks. Dose and } \\
\text { frequency of dosing are } \\
\text { guided by a nomogram. }\end{array}$ & $\begin{array}{l}\text { Serum IgE }>30<1500 \\
I U / m L \\
\text { Perennial aeroallergen } \\
\text { Blood eosinophil count } \\
\geq 300 \text { cells } / \mu \mathrm{L}\end{array}$ & $\begin{array}{l}\text { Local skin reaction } \\
\text { and pain, } \\
\text { anaphylaxis } \\
(0.1-0.2 \% \text { of adults } \\
\text { and adolescents). }\end{array}$ \\
\hline Mepolizumab & Anti-IL-5 & $\begin{array}{l}\text { Add on therapy in } \\
\text { patients with } \\
\text { severe asthma with } \\
\text { an eosinophilic } \\
\text { phenotype, and } \\
\text { a history of asthma } \\
\text { exacerbations. }\end{array}$ & $\begin{array}{l}\text { Adults and } \\
\text { children } \geq \\
6 \text { years }\end{array}$ & $\begin{array}{l}100 \mathrm{mg} \text { SC every } 4 \\
\text { weeks in adults and } \\
\text { adolescents } \geq 12 \\
\text { years. } \\
40 \mathrm{mg} \text { SC every } 4 \text { weeks } \\
\text { in children aged 6-II } \\
\text { years. }\end{array}$ & $\begin{array}{l}\text { Blood eosinophil count } \\
\geq 300 \text { cells/ } \mu \mathrm{L} \text {, or blood } \\
\text { eosinophil count } \geq 150 \\
\text { cells/ } \mu \mathrm{L} \text { in patients with } \\
\text { well characterized } \\
\text { eosinophilic asthma or } \\
\text { requiring regular OCS. }\end{array}$ & $\begin{array}{l}\text { Infections, } \\
\text { worsening of } \\
\text { asthma, headache, } \\
\text { local skin reactions, } \\
\text { back pain, fatigue. }\end{array}$ \\
\hline Dupilumab & $\begin{array}{l}\text { Anti-IL-4 } \\
\text { receptor } \alpha \text { - } \\
\text { subunit, } \\
\text { blocking } \\
\text { signaling } \\
\text { induced by } \\
\text { both IL-4 and } \\
\text { IL-I3. }\end{array}$ & $\begin{array}{l}\text { Add-on treatment } \\
\text { of severe asthma } \\
\text { with type } 2 \\
\text { inflammation, } \\
\text { peripheral } \\
\text { eosinophilia and } \\
\text { high values of } \\
\text { FeNo. }\end{array}$ & $\begin{array}{l}\text { Adults and } \\
\text { adolescents } \\
\geq 12 \text { years }\end{array}$ & $\begin{array}{l}\text { I)For severe asthma in } \\
\text { patients taking OCS or } \\
\text { in patients with AD and } \\
\text { CRSwNP first dose is } 2 \\
\text { injections of } 300 \mathrm{mg} \\
\text { followed by } 300 \mathrm{mg} \\
\text { every } 2 \text { weeks. } \\
\text { 2)For all other patients } \\
\text { with asthma the first } \\
\text { dose is } 2 \text { injections of } \\
200 \mathrm{mg} \text { followed by one } \\
\text { injection of } 200 \mathrm{mg} \text {. }\end{array}$ & $\begin{array}{l}\text { Peripheral eosinophilia } \\
\text { ( } \geq 150 \text { cells } / \mu \mathrm{L} \text { ), and/ } \\
\text { or FeNo } \geq 25 \mathrm{ppb}\end{array}$ & $\begin{array}{l}\text { Injection-site } \\
\text { erythema, pain, } \\
\text { edema, pruritus, } \\
\text { conjunctivitis, eye } \\
\text { pruritus, } \\
\text { blepharitis, oral } \\
\text { herpes, } \\
\text { eosinophilia, } \\
\text { headache. }\end{array}$ \\
\hline
\end{tabular}

Abbreviations: AD, atopic dermatitis; CRSwNP, chronic rhinosinusitis with nasal polyposis; FeNo, fractional exhaled nitric oxide; IgE, immunoglobulin E; IL, interleukin, OCS, oral corticosteroid; SC, subcutaneous. 
dose and frequency of subcutaneous (SC) administrations of omalizumab are established by a nomogram obtained from total serum $\operatorname{IgE}$ levels and body weight (kilograms). ${ }^{30}$ Recent studies demonstrated that omalizumab is more effective in asthmatic children showing multiple allergic comorbidities (multiple sensitizations, atopic dermatitis, and food allergy), and high peripheral eosinophil counts $(>300$ cells $/ \mu \mathrm{L})$, pretreatment total $\operatorname{IgE}$, fractional exhaled nitric oxide ( $\mathrm{FeNO}>20 \mathrm{ppb}$ ) and elevated serum periostin. ${ }^{32,33}$ Nevertheless, there are not enough data on validated biomarkers predicting response to omalizumab therapy in children; thus, further investigation is needed. ${ }^{28,34}$

\section{Efficacy and Safety}

Several randomized controlled trials established the efficacy and safety of omalizumab in pediatrics. ${ }^{35-38}$ Notably, pediatric studies reported that omalizumab reduced the rate of acute asthma attacks, hospitalizations, and the need for OCS. ${ }^{39-43}$

Besides, omalizumab significantly improved the asthma control and the QoL of patients. ${ }^{39-43}$ Finally, pediatric patients treated with omalizumab developed a lower number of seasonal exacerbations induced by respiratory viruses than controls. ${ }^{35-37}$

A large amount of data from trials and prospective studies showed that omalizumab is generally well tolerated in children and adolescents. ${ }^{31,39,44-48}$ The risk of severe or life threatening drug-related events, such as anaphylaxis, has been reported in $0.1-0.2 \%$ of adults and adolescents treated with omalizumab and was not observed in pediatric studies. ${ }^{44} 46$ Local skin reaction and pain at the injection site are the main side effects reported in observational studies and generally have a quick resolution. ${ }^{40-42}$ Finally, there is no evidence to support an increased risk of malignancy. However, long-term monitoring studies on patients treated with omalizumab are still needed to confirm the good safety profile. ${ }^{28,34,46,47}$

\section{Mepolizumab}

\section{Mechanism of Action and Dosage}

Mepolizumab is a humanized monoclonal antibody that binds to and inhibits circulating IL-5. Mepolizumab has recently been approved as additional maintenance therapy for severe eosinophilic asthma (Table 3). ${ }^{49,50}$ The Food and Drug Administration (FDA) and the European Medicines Agency (EMA) recently approved the use of mepolizumab in asthmatic patients aged $\geq 6$ years with refractory disease, an eosinophilic phenotype, and a history of asthma exacerbations. ${ }^{51,52}$

Currently, the recommended dosage of mepolizumab is $100 \mathrm{mg}$ for adults and children aged $\geq 12$ years, and $40 \mathrm{mg}$ for children aged $6-11$ years. ${ }^{53}$

Although standardized response criteria are still lacking, clinical and laboratory parameters have been proposed as predictor tools for therapy response. ${ }^{54}$ Blood eosinophil count $\geq 300$ cells $/ \mu \mathrm{L}$, (or $\geq 150$ cells $/ \mu \mathrm{L}$ in patients with well-characterized eosinophilic asthma or requiring several cycles with OCS) and, more recently, the improvement in FEV1 value are currently considered as parameters of response to mepolizumab therapy. ${ }^{54-56}$ Moreover, the improvement of QoL, exacerbations, and physical fitness have also been reported as clinical predictors for response to therapy. ${ }^{56}$

There is no validated recommendation on mepolizumab discontinuation. According to the National Institute for Health and Care Excellence (NICE) guidelines, the decision to continue mepolizumab therapy is based on more than $50 \%$ of reduction of asthma exacerbations after 12 months of treatment. ${ }^{57}$ Besides, as reported in several studies, continued dosing is required to maintain the positive therapeutical effect. ${ }^{54}$ It was reported that patients who discontinued mepolizumab might relapse after 3-6 months, showing high peripheral eosinophilia, and a significant increase in asthma attack rate, and the Asthma Control Questionnaire-5 (ACQ-5) score. ${ }^{58}$

\section{Efficacy and Safety}

Two double-blind, randomized, placebo-controlled trials evaluated the efficacy and safety of mepolizumab in adults and adolescents with uncontrolled eosinophilic asthma. ${ }^{59,60}$ Moreover, these trials showed a significant decrease in the rate of asthma exacerbations and QoL, mostly in patients with a baseline blood eosinophil count of at least 500 cells $/ \mu \mathrm{L} .{ }^{59} \mathrm{In}$ a recent trial, Khatri et al evaluated the long-term efficacy of mepolizumab. Although only a small proportion of adolescents were enrolled in this study, all pediatric patients had reached the endpoints, including the annualized severe exacerbation rates, changes from baseline in ACQ-5 score, and blood eosinophil counts. ${ }^{61}$ The Steroid Reduction with Mepolizumab (SIRIUS) study showed that patients treated with mepolizumab reported a significant reduction in OCS use and a remarkable improvement in their symptoms and lung function. ${ }^{55}$ Besides, the COSMOS study highlighted a long-lasting and stable effect in the mepolizumab group over time and a significant improvement of FEV1 and ACQ- 
5 score. $^{62}$ There is poor evidence of the effectiveness of mepolizumab in asthmatic children younger than 12 years. In the open-label study by Gupta et al the primary endpoint was the assessment of the pharmacokinetics and pharmacodynamics in children with 6 to 11 years-of-age; thus, the efficacy of mepolizumab was difficult to evaluate.Thereforefurther research is needed. ${ }^{63}$

In placebo-controlled trials, mepolizumab also showed a notable safety profile and appeared well tolerated. $^{50,55,58,60,63}$ The most commonly reported side effects were reactions at the site of injection, headaches, fatigue, respiratory infections, and worsening of asthma. $^{50,55,60,64}$

\section{Reslizumab}

\section{Mechanism of Action and Dosage}

Reslizumab is a monoclonal antibody that binds circulating IL-5. Reslizumab was approved as additional therapy for patients with severe uncontrolled eosinophilic asthma aged $\geq$ 18 years. $^{65}$ In particular, the NICE Appraisal Committee recommends the use of reslizumab for the treatment of severe asthma despite a high-dose ICS plus another therapy, when: 1) peripheral eosinophils are $\geq 400$ cells $/ \mu \mathrm{L}, 2$ ) patient had $\geq$ three asthma exacerbations in a year, and 3) company provides the monoclonal antibody at the agreed discount level. ${ }^{66}$ The recommended dosage of reslizumab is $3.0 \mathrm{mg} / \mathrm{kg}$ IV every 4 weeks. $^{67}$

Bateman et al proposed as responder criteria 1) an improvement of the ACQ and Assessment of Quality of Life (AQoL), 2) pretreatment value of FEV1 and 3) the number of asthma attacks during the year before the beginning of therapy and the first 16 weeks of treatment. ${ }^{68}$ However, these parameters are not validated, and further studies are required. ${ }^{68}$ Data on the follow-up of patients who discontinued reslizumab are still incomplete.

\section{Efficacy and Safety}

A Phase III randomized placebo-controlled trial demonstrated that reslizumab significantly improved lung function, QoL, respiratory symptoms, and the number of asthma exacerbations, especially in patients with a lateonset asthma phenotype. ${ }^{69-72}$

Reslizumab improved lung function and reduced asthma symptoms after 2-3 days from the first infusion. These effects have been maintained for up to 24 months.73,74 Reslizumab was also effective in reducing OCS use, local and systemic eosinophilia. ${ }^{75}$ Reslizumab was not effective in patients aged 12-17 years of age. Thus, studies in a pediatric population ( $<12$ years) were currently waived. $^{65}$

Reslizumab is well tolerated. The most common side effects were infections, headache, worsening of asthma, and rarely local infusion-related symptoms. No cases of anaphylaxis have been described. No changes in the incidence of malignancies and mortality were noted in patients treated with reslizumab. ${ }^{74}$

\section{Benralizumab}

\section{Mechanism of Action and Dosage}

Benralizumab is a monoclonal antibody that specifically binds the IL-5R $\alpha$, reducing circulating eosinophils and modulating eosinophil-associated proteins and genes. ${ }^{76}$ In the US, benralizumab was approved as an additional therapy for severe eosinophilic asthma in patients $\geq 12$ years. $^{77,78}$ In Europe, benralizumab is recommended as additional therapy of severe uncontrolled eosinophilic asthma in adults, despite the high dosage of ICS and longacting $\beta 2$-agonists (LABA). ${ }^{77,78}$

Clinical, laboratory, and pulmonary functional features, such as pretreatment blood eosinophils count ( $\geq 300$ cells/ $\mathrm{mm} 3$ ), positive history of nasal polyposis, onset age at asthma diagnosis, forced vital capacity (FVC), exacerbation frequency, and OCS use, seem to be valid indicators of treatment response. ${ }^{79,80}$

The therapy is administered $30 \mathrm{mg}$ SC every four weeks for the first three doses, then every eight weeks. ${ }^{81}$

\section{Efficacy and Safety}

Two randomized, double-blind, placebo-controlled phase III trials showed a significant improvement in the number of asthma exacerbations, pretreatment FEV1, and asthma symptoms in adult patients treated with benralizumab compared to controls. $^{82,83}$ Data for children younger than 12 years of age are currently not available. Moreover, in a subgroup analysis of 108 adolescents aged 12-17 years, no significant effect on asthma exacerbation rates was noted (Fansera European Medicines Agencyhttps:/ec.europa.eu/health/documents/ communityregister/2018/20180108139598/anx 139598 en. pdf https://www.ema.europa.eu/en/medicines/human/EPAR/ fasenra) The BORA phase III trial showed that $1-2 \%$ of patients in the benralizumab group experienced infections. ${ }^{84}$ No evidence currently described malignancies or deaths due to benralizumab administration. ${ }^{82,83,85}$ 


\section{Dupilumab}

\section{Mechanism of Action and Dosage}

Dupilumab is a fully human monoclonal antibody, which blocks IL-4 and IL-13 receptors (Table 3). ${ }^{86}$ Dupilumab is indicated asadditional maintenance treatment for patients with type 2 asthma characterized by high blood eosinophils and/or FeNO and inadequately controlled with highdose of ICS plus another medication. ${ }^{87,88}$ Dupilumab was approved in the US and Europe for patients aged $\geq 12$ years with moderate-to-severe asthma and peripheral eosinophilia ( $\geq 300$ cells $/ \mu \mathrm{L}$ ). ${ }^{89}$ Dupilumab is subcutaneously administered $400 \mathrm{mg}$ once, then $200 \mathrm{mg}$ every two weeks, or $600 \mathrm{mg}$ once, then $300 \mathrm{mg}$ every two weeks. ${ }^{89}$

\section{Efficacy and Safety}

In three main clinical trials, dupilumab showed reduced severe asthma attacks, improved lung function, and reduced OCS use in adults and adolescents. ${ }^{90,91}$ The QUEST trial reported that dupilumab significantly reduced the annual rate of asthma exacerbations in patients $\geq 12$ years of age with uncontrolled moderate-to-severe asthma. ${ }^{90}$ In particular, this positive effect was mainly observed in patients with high peripheral eosinophilia (> 300 cells $/ \mathrm{mm}^{3}$ ) and FeNO $>25$ ppb. ${ }^{90}$ Moreover, dupilumab significantly improved lung function and reduced the number of asthma exacerbations. ${ }^{92}$

Two-phase III ongoing trials (NCT02948959 and NCT03560466, respectively) evaluated the efficacy, safety, and tolerability of dupilumab in children aged 6 to $<12$ years with severe uncontrolled asthma. ${ }^{93}$

Transient eosinophilia in the dupilumab group was reported in both QUEST and VENTURE trials and was not correlated with severe side effects. ${ }^{91,94,95}$ The injection-site reactions occurred in $9 \%$ and $0 \%$ of adolescents treated with $200 \mathrm{mg}$ and $300 \mathrm{mg}$ of dupilumab. ${ }^{93} \mathrm{In}$ adults, cases of eosinophilic pneumonia and eosinophilic granulomatosis with polyangiitis have been described in the dupilumab group. Fortunately, these complications have not been reported in adolescents.

\section{How to Choose the Best Therapeutic Option}

The choice of the most appropriate biologic drug for asthmatic patients is a challenge for allergists. Firstly, pediatric allergists should assess the severity of asthma, excluding potential comorbidities and the poor adherence to inhalation therapy. Physicians should also characterize children with severe asthma, considering their phenotype (type 2 or non-type 2) and endotype (allergic or eosinophilic). Allergic severe asthma typically affects children with a clinical history of allergic rhinitis, positive skin prick tests, and high levels of total IgE ( $\geq 100 \mathrm{IU} / \mathrm{mL}$ ) and FeNO. ${ }^{96}$ In these patients, omalizumab may be currently considered the first therapeutical choice. Biological therapies with IL5/5Ra antagonists are generally prescribed in patients with severe uncontrolled eosinophilic asthma, which is characterized by peripheral eosinophilia ( $\geq 150$ cells $/ \mu \mathrm{L}$ ). ${ }^{96}$ Chan et al recently proposed an algorithm that may help physicians identify the best therapeutic option among the available biological therapies. ${ }^{97}$ Based on this algorithm, patients with severe eosinophilic asthma may be first treated with IL-5 antagonists (mepolizumab, benralizumab, and reslizumab), effectively reducing asthmatic exacerbations. Eosinophils are the central driver of type 2 inflammation and play a crucial role in maintaining airway inflammation in patients that usually respond well to ICS. ${ }^{8}$ In asthmatic patients, sputum eosinophilia predicts steroid response; however, sputum induction is not feasible in children, it is burdened with execution difficulties, and processing requires expertise and is time consuming. ${ }^{8}$ Blood eosinophils have been shown to be significantly predictive of sputum eosinophilia, even with a lower specificity because of the influence of potential confounding factors (ie allergen exposure, parasitic infections, and current corticosteroid therapy). ${ }^{8}$ Notably, OCS therapy may often reduce the peripheral eosinophil count in asthmatic patients. ${ }^{98}$ However, Mukherjee et al have recently found that there is no correlation between sputum and blood eosinophils in a small group of adult patients with severe asthma treated with daily OCS. ${ }^{99}$

Dupilumab may be considered a first-line therapy in patients with severe asthma with FeNO $\geq 25 \mathrm{ppb}$ and other allergic comorbidities, such as eosinophilic esophagitis, CRSwNP, and atopic dermatitis.

In our opinion, total IgE, blood eosinophil count and FeNO should be used as a surrogate of airway Type-2 inflammation among asthma patients and should be compositely considered when choosing an initial biologic agent for asthma treatment.

\section{Conclusion}

The introduction of monoclonal antibody agents in asthma treatment is a milestone in the application of personalized medicine. Since omalizumab was approved for asthma management, different biological therapies have revolutionized the therapeutical approach of severe uncontrolled allergic diseases in children and adolescents. However, comparative 
studies are required to help clinicians choosing the best therapeutic option for patients with severe asthma who are eligible for more than one treatment. Moreover, standardized algorithms for the management of pediatric severe asthma should be realized, as already available in adults.

The research on asthma pathogenesis is ongoing and aims to improve the mechanisms driving the T2-high and T2-low endotypes. Identifying novel predictive biomarkers is a future goal in asthma management that may help physicians identify and select children and adolescents with severe asthma for innovative biologic therapies.

\section{Acknowledgment}

Martina Votto and Maria De Filippo are co-first authors.

\section{Disclosure}

The authors report no conflicts of interest in this work.

\section{References}

1. Sánchez-Borges M, Martin BL, Muraro AM, et al. The importance of allergic disease in public health: an iCAALL statement. World Allergy Organ J. 2018;11(1):8. doi:10.1186/s40413-018-0187-2

2. Licari A, Manti S, Marseglia A, et al. Biologics in children with allergic diseases. Curr Pediatr Rev. 2020;16(2):140-147. doi:10. 2174/1573396315666191029123822

3. Licari A, Ciprandi R, Marseglia G, et al. Anxiety and depression in adolescents with severe asthma and in their parents: preliminary results after 1 year of treatment. Behav Sci (Basel). 2019;9(7):78. doi:10.3390/bs9070078

4. Licari A, Ciprandi R, Marseglia G, et al. Anxiety and depression in adolescents with asthma and in their parents: a study in clinical practice. Monaldi Arch Chest Dis. 2019;89(3):3. doi:10.4081/ monaldi.2019.1063

5. Licari A, Ciprandi R, Marseglia G, et al. Anxiety/depression changes are associated with improved asthma control perception in asthmatic adolescents after adequate management. Eur Ann Allergy Clin Immunol. 2019;51(4):190-192. doi:10.23822/EurAnnACI.17641489.97

6. Votto M, Castagnoli R, De Filippo M, et al. Behavioral issues and quality of life in children with eosinophilic esophagitis. Minerva Pediatr. 2020;72(5):424-432. doi:10.23736/S0026-4946.20.05913-7

7. Manka LA, Wechsler ME. New biologics for allergic diseases. Expert Rev Clin Immunol. 2018;14(4):285-296. doi:10.1080/1744666X.20 18.1459188

8. Licari A, Castagnoli R, Brambilla I, et al. Asthma endotyping and biomarkers in childhood asthma. Pediatr Allergy Immunol Pulmonol. 2018;31(2):44-55. doi:10.1089/ped.2018.0886

9. Rusconi F, Fernandes RM, Pijnenburg MWH, et al. The severe paediatric asthma collaborative in Europe (SPACE) ERS clinical research collaboration: enhancing participation of children with asthma in therapeutic trials of new biologics and receptor blockers. Eur Respir J. 2018;52(4):1801665. doi:10.1183/13993003.01665-2018

10. Montalbano L, Ferrante G, Montella S, et al. Relationship between quality of life and behavioural disorders in children with persistent asthma: a Multiple Indicators Multiple Causes (MIMIC) model. Sci Rep. 2020;10(1):6957. doi:10.1038/s41598-020-62264-9
11. Licari A, Brambilla I, Marseglia A, et al. Difficult vs. severe asthma: definition and limits of asthma control in the pediatric population. Front Pediatr. 2018;6:170. doi:10.3389/fped.2018.00170

12. Holguin F, Cardet JC, Chung KF, et al. Management of severe asthma: a European Respiratory Society/American Thoracic Society guideline. Eur Respir J. 2020;55(1):1900588. doi:10.1183/ 13993003.00588-2019

13. Global Initiative for Asthma. Global strategy for asthma management and prevention [homepage on the Internet]. Available from: https:// ginasthma.org/wp-content/uploads/2020/04/GINA-2020-full-report_final-_wms.pdf. Accessed February 22, 2021.

14. BTS/SIGN British guideline on the management of asthma [homepage on the Internet]. Available from: https://www.brit-thoracic.org.uk/qual ity-improvement/guidelines/asthma/. Accessed February 22, 2021.

15. Chung KF, Wenzel SE, Brozek JL, et al. International ERS/ATS guidelines on definition, evaluation and treatment of severe asthma. Eur Respir J. 2014;43(2):343-373. doi:10.1183/09031936.00202013

16. Miraglia Del Giudice M, Marseglia GL, Leonardi S, et al. Fractional exhaled nitric oxide measurements in rhinitis and asthma in children. Int J Immunopathol Pharmacol. 2011;24(4Suppl):29-32. doi:10.1177/03946320110240S407

17. Licari A, Castagnoli R, Denicolò CF, et al. The nose and the lung: united airway disease? Front Pediatr. 2017;5:44. doi:10.3389/fped.2017.00044

18. Licari A, Brambilla I, De Filippo M, et al. The role of upper airway pathology as a comorbidity in severe asthma. Expert Rev Respir Med. 2017;11(11):855-865. doi:10.1080/17476348.2017.1381564

19. Fitzpatrick AM. Severe asthma in children: lessons learned and future directions. J Allergy Clin Immunol Pract. 2016;4(1):11-19. doi:10.1016/j.jaip.2015.10.008

20. Fleming L, Murray C, Bansal AT, et al. The burden of severe asthma in childhood and adolescence: results from the paediatric U-BIOPRED cohorts. Eur Respir J. 2015;46(5):1322-1333. doi:10.1183/13993003.00780-2015

21. Montella S, Baraldi E, Cazzato S, et al. Severe asthma features in children: a case-control online survey. Ital J Pediatr. 2016;42(1):9. doi:10.1186/s13052-016-0217-z

22. Ramratnam SK, Bacharier LB, Guilbert TW. Severe asthma in children. J Allergy Clin Immunol Pract. 2017;5(4):889-898. doi:10.1016/j.jaip.2017.04.031

23. Licari A, Castagnoli R, Brambilla I, et al. New approaches for identifying and testing potential new anti-asthma agents. Expert Opin Drug Discov. 2018;13(1):51-63. doi:10.1080/17460441.2018.1396315

24. Robinson D, Humbert M, Buhl R, et al. Revisiting type 2-high and type 2-low airway inflammation in asthma: current knowledge and therapeutic implications. Clin Exp Allergy. 2017;47(2):161-175. doi:10.1111/cea.12880

25. Samitas K, Zervas E, Gaga M. T2-low asthma: current approach to diagnosis and therapy. Curr Opin Pulm Med. 2017;23(1):48-55. doi:10.1097/MCP.0000000000000342

26. Manti S, Brown P, Perez MK, et al. The role of neurotrophins in inflammation and allergy. Vitam Horm. 2017;104:313-341.

27. Licari A, Marseglia GL. Current and future challenges in pediatric severe asthma. Curr Med Res Opin. 2018;34(5):943-944. doi:10.1080/03007995.2018.1439463

28. Licari A, Manti S, Chiappini E, et al. Severe asthma in children: current goals and unmet needs. Pediatr Allergy Immunol. 2020;31 (Suppl 24):40-42. doi:10.1111/pai.13168

29. Licari A, Marseglia G, Castagnoli R, et al. The discovery and development of omalizumab for the treatment of asthma. Expert Opin Drug Discov. 2015;10(9):1033-1042. doi:10.1517/17460441.2015.1048220

30. Licari A, Marseglia A, Caimmi S, et al. Omalizumab in children. Paediatr Drugs. 2014;16(6):491-502. doi:10.1007/s40272-014-0107-z

31. Chipps BE, Lanier B, Milgrom H, et al. Omalizumab in children with uncontrolled allergic asthma: review of clinical trial and real-world experience. J Allergy Clin Immunol. 2017;139(5):1431-1444. doi:10.1016/j.jaci.2017.03.002 
32. Sesé L, Schneider M, Bourgoin M, et al. Asthma with multiple allergic comorbidities is associated with complete response to omalizumab. Clin Exp Allergy. 2019;49(5):733. doi:10.1111/ cea. 13373

33. Sorkness CA, Wildfire JJ, Calatroni A, et al. Reassessment of omalizumab-dosing strategies and pharmacodynamics in inner-city children and adolescents. J Allergy Clin Immunol Pract. 2013;1 (2):163-171. doi:10.1016/j.jaip.2013.01.011

34. Licari A, Manti S, Castagnoli R, et al. Targeted therapy for severe asthma in children and adolescents: current and future perspectives. Paediatr Drugs. 2019;21(4):215-237. doi:10.1007/s40272-01900345-7

35. Brodlie M, McKean MC, Moss S, et al. The oral corticosteroid-sparing effect of omalizumab in children with severe asthma. Arch Dis Child. 2012;97(7):604-609. doi:10.1136/archdischild-2011-301570

36. Busse WW, Morgan WJ, Gergen PJ, et al. Randomized trial of omalizumab (anti-IgE) for asthma in inner-city children. $N$ Engl J Med. 2011;364(11):1005-1015. doi:10.1056/NEJMoa1009705

37. Lanier B, Bridges T, Kulus M, et al. Omalizumab for the treatment of exacerbations in children with inadequately controlled allergic (IgE-mediated) asthma. $J$ Allergy Clin Immunol. 2009;124 (6):1210-1216. doi:10.1016/j.jaci.2009.09.021

38. Teach SJ, Gill MA, Togias A, et al. Preseasonal treatment with either omalizumab or an inhaled corticosteroid boost to prevent fall asthma exacerbations. J Allergy Clin Immunol. 2015;136(6):1476-1485. doi:10.1016/j.jaci.2015.09.008

39. Rodrigo GJ, Neffen H. Systematic review on the use of omalizumab for the treatment of asthmatic children and adolescents. Pediatr Allergy Immunol. 2015;26(6):551-556. doi:10.1111/pai.12405

40. Deschildre A, Marguet C, Salleron J, et al. Add-on omalizumab in children with severe allergic asthma: a 1-year real life survey. Eur Respir J. 2013;42(5):1224-1233. doi:10.1183/09031936. 00149812

41. Deschildre A, Marguet C, Langlois C, et al. Real-life long-term omalizumab therapy in children with severe allergic asthma. Eur Respir J. 2015;46(3):856-859. doi:10.1183/09031936.00008115

42. Licari A, Castagnoli R, Denicolo C, et al. Omalizumab in children with severe allergic asthma: the Italian real-life experience. Curr Respir Med Rev. 2017;13(1):36-42. doi:10.2174/1573398X1366 6170426094536

43. Pitrez PM, de Souza RG, Roncada C, et al. Impact of omalizumab in children from a middle-income country with severe therapy-resistant asthma: a Real-Life Study. Pediatr Pulmonol. 2017;52 (11):1408-1413. doi:10.1002/ppul.23845

44. Berger W, Gupta N, McAlary M, et al. Evaluation of long-term safety of the anti-IgE antibody, omalizumab, in children with allergic asthma. Ann Allergy Asthma Immunol. 2003;91(2):182-188. doi:10.1016/S1081-1206(10)62175-8

45. Milgrom H, Fowler-Taylor A, Vidaurre CF, et al. Safety and tolerability of omalizumab in children with allergic (IgE-mediated) asthma. Curr Med Res Opin. 2011;27(1):163-169. doi:10.1185/ 03007995.2010.539502

46. Busse W, Buhl R, Fernandez vidaurre C, et al. Omalizumab and the risk of malignancy: results from a pooled analysis. J Allergy Clin Immunol. 2012;129(4):983-989. doi:10.1016/j.jaci.2012.01.033

47. Long A, Rahmaoui A, Rothman KJ, et al. Incidence of malignancy in patients with moderate-to- severe asthma treated with or without omalizumab. J Allergy Clin Immunol. 2014;134(3):560-567. doi:10.1016/j.jaci.2014.02.007

48. Normansell R, Walker S, Milan SJ, et al. Omalizumab for asthma in adults and children. Cochrane Database Syst Rev. 2014;1:CD003559.

49. European Medicines Agency. Nucala ${ }^{\circledR}$ [homepage on the Internet]. Available from: https://www.ema.europa.eu/en/medicines/human/ EPAR/nucala. Accessed April 23, 2021.
50. Flood-Page P, Swenson C, Faiferman I, et al. A study to evaluate safety and efficacy of mepolizumab in patients with moderate persistent asthma. Am J Respir Crit Care Med. 2007;176(11):1062-1071. doi:10.1164/rccm.200701-085OC

51. Food and Drug Administration. Nucala ${ }^{\circledR}$ [homepage on the Internet]. Available from: https:/www.accessdata.fda.gov/drugsatfda docs/ label/2019/761122s000lbl.pdf. Accessed February 22, 2021.

52. GSK European Commission approves Nucala (mepolizumab) for the treatment of children with severe asthma. [homepage on the Internet]. Available from: https://www.gsk.com/en-gb/media/pressreleases/european-commission-approves-nucala-mepolizumab-forthe-treatment-of-children-with-severe-asthma/. Accessed February 22, 2021.

53. Kline GS. Nucala ${ }^{\circledR}$ (mepolizumab) prescribing information. [homepage on the Internet]. Available from: https://www.accessdata.fda. gov/drugsatfda_docs/label/2015/125526Orig1s000Lbl.pdf. Accessed April 27, 2021.

54. Drick N, Seeliger B, Welte T, et al. Anti-IL-5 therapy in patients with severe eosinophilic asthma-clinical efficacy and possible criteria for treatment response. BMC Pulm Med. 2018;18(1):119. doi:10.1186/ s12890-018-0689-2

55. Bel EH, Wenzel SE, Thompson PJ, et al. Oral glucocorticoid-sparing effect of mepolizumab in eosinophilic asthma. $N$ Engl $J$ Med. 2014;371(13):1189-1197. doi:10.1056/NEJMoa1403291

56. Haldar P. Patient profiles and clinical utility of mepolizumab in severe eosinophilic asthma. Biologics. 2017;11:81-95. doi:10.2147/ BTT.S93954

57. Mepolizumab for treating severe refractory eosinophilic asthma. NICE technology appraisal guidance [TA431] [homepage on the Internet]. Available from: https://www.nice.org.uk/guidance/ta431. Accessed February 22, 2021.

58. Farne HA, Wilson A, Powell C, et al. Anti-IL5 therapies for asthma. Cochrane Database Syst Rev. 2017;9:CD010834. doi:10.1002/ 14651858.CD010834.pub3

59. Pavord ID, Kom S, Howarth P, et al. Mepolizumab for severe eosinophilic asthma (DREAM): a multicentre, double-blind, placebo-controlled trial. Lancet. 2012;380(9842):651-659. doi:10. 1016/S0140-6736(12)60988-X

60. Ortega HG, Liu MC, Pavord ID, et al. Mepolizumab treatment in patients with severe eosinophilic asthma. $N$ Engl J Med. 2014;371 (13):1198-1207. doi:10.1056/NEJMoa1403290

61. Khatri S, Moore W, Gibson PG, et al. Assessment of the long-term safety of mepolizumab and durability of clinical response in patients with severe eosinophilic asthma. J Allergy Clin Immunol. 2018;43 (5): 1742-1751.

62. Lugogo N, Domingo C, Chanez P, et al. Long-term efficacy and safety of mepolizumab in patients with severe eosinophilic asthma: a Multi-Center, Open-Label, Phase IIIb Study. Clin Ther. 2016;38 (9):2058-2070. doi:10.1016/j.clinthera.2016.07.010

63. Gupta A, Pouliquen I, Austin D, et al. Subcutaneous mepolizumab in children aged 6 to 11 years with severe eosinophilic asthma. Pediatr Pulmonol. 2019;54(12):1957-1967. doi:10.1002/ppul.24 508

64. Henriksen DP, Bodtger U, Sidenius K, et al. Efficacy, adverse events, and inter-drug comparison of mepolizumab and reslizumab anti-IL-5 treatments of severe asthma - a systematic review and meta-analysis. Eur Clin Respir J. 2018;5(1):1536097. doi:10.1080/20018525.20 18.1536097

65. Pediatric postmarketing pharmacovigilance review: cinqair ${ }^{\mathbb{B}}$ (Reslizumab). [homepage on the Internet]. Available from: https:// www.fda.gov/media/114068/download. Accessed April 27, 2021.

66. Cooper K, Frampton G, Harris P, et al. Reslizumab for treating asthma with elevated blood eosinophils inadequately controlled by inhaled corticosteroids: an evidence review group perspective of a NICE single technology appraisal. Pharmacoeconomics. 2018;36 (5):545-553. doi:10.1007/s40273-017-0608-z 
67. Teva. Cinqair (reslizumab) prescribing information. [homepage on the Internet]. Available from: https://hcp.cinqair.com/dosageand-administration.aspx. Accessed April 27, 2021.

68. Bateman ED, Djukanović R, Castro M, et al. Predicting responders to reslizumab after 16 weeks of treatment using an algorithm derived from clinical studies of severe eosinophilic asthma patients. Am J Respir Crit Care Med. 2019;199(4):489-495. doi:10.1164/ rccm.201708-16680C

69. Corren J, Weinstein S, Janka L, et al. Phase 3 study of reslizumab in patients with poorly controlled asthma: effects across a broad range of eosinophil counts. Chest. 2016;150(4):799-810. doi:10.1016/j. chest.2016.03.018

70. Bjermer L, Lemiere C, Maspero J, et al. Reslizumab for inadequately controlled asthma with elevated blood eosinophil levels: a Randomized Phase 3 Study. Chest. 2016;150(4):789-798. doi:10.1016/j.chest.2016.03.032

71. Castro M, Zangrilli J, Wechsler ME, et al. Reslizumab for inadequately controlled asthma with elevated blood eosinophil counts: results from two multicentre, parallel, double-blind, randomised, placebo-controlled, phase 3 trials. Lancet Respir Med. 2015;3 (5):355-366. doi:10.1016/S2213-2600(15)00042-9

72. Brusselle G, Germinaro M, Weiss S, et al. Reslizumab in patients with inadequately controlled late-onset asthma and elevated blood eosinophils. Pulm Pharmacol Ther. 2017;43:39-45. doi:10.1016/j. pupt.2017.01.011

73. Chanez P, McDonald M, Garin M, et al. Early decreases in blood eosinophil levels with reslizumab. J Allergy Clin Immunol. 2019;143 (4):1653-1655. doi:10.1016/j.jaci.2018.12.997

74. Murphy K, Jacobs J, Bjermer L, et al. Long-term safety and efficacy of reslizumab in patients with eosinophilic asthma. J Allergy Clin Immunol Pract. 2017;5(6):1572-1581. doi:10.1016/j.jaip.2017.08. 024

75. Mukherjee M, Aleman Paramo F, Kjarsgaard M, et al. Weightadjusted intravenous reslizumab in severe asthma with inadequate response to fixed-dose subcutaneous mepolizumab. Am J Respir Crit Care Med. 2018;197(1):38-46. doi:10.1164/rccm.2017071323OC

76. Sridhar S, Liu H, Pham TH, et al. Modulation of blood inflammatory markers by benralizumab in patients with eosinophilic airway diseases. Respir Res. 2019;20(1):14. doi:10.1186/s12931-018-0968-8

77. AstraZeneca. Fasenra ${ }^{\circledR}$ (benralizumab) prescribing information. [homepage on the Internet]. Available from: https://www.accessdata. fda.gov/drugsatfda docs/label/2017/761070s000lbl.pdf. Accessed February 22, 2021.

78. AstraZeneca. Fasenra (benralizumb). Summary of product characteristics. [homepage on the Internet]. Available from: http://ec.europa. eu/health/documents/communityregister/2018/20180108139598/anx 139598 en.pdf. Accessed April 27, 2021.

79. Bagnasco D, Caminati M, Ferrando M, et al. Anti-IL-5 and IL-5Ra: efficacy and safety of new therapeutic strategies in severe uncontrolled asthma. Biomed Res Int. 2018;2018:5698212. doi:10.1155/ 2018/5698212

80. Bleecker ER, Wechsler ME, Fitzgerald JM, et al. Baseline patient factors impact on the clinical efficacy of benralizumab for severe asthma. Eur Respir J. 2018;52(4):1800936. doi:10.1183/ 13993003.00936-2018

81. Matera MG, Calzetta L, Rinaldi B, et al. Pharmacokinetic/pharmacodynamic drug evaluation of benralizumab for the treatment of asthma. Expert Opin Drug Metab Toxicol. 2017;13(9):1007-1013. doi:10.1080/17425255.2017.1359253

82. Bleecker ER, Fitzgerald JM, Chanez P, et al. Efficacy and safety of benralizumab for patients with severe asthma uncontrolled with highdosage inhaled cor-ticosteroids and long-acting $\beta(2)$-agonists (SIROCCO): a randomised, multicentre, placebo-controlled phase 3 trial. Lancet. 2016;388(10056):2115-2127. doi:10.1016/S01406736(16)31324-1
83. Fitzgerald JM, Bleecker ER, Nair P, et al. Benralizumab, an antiinterleukin-5 receptor $\alpha$ monoclonal antibody, as add-on treatment for patients with severe, uncontrolled, eosinophilic asthma (CALIMA): a randomised, double-blind, placebo-controlled phase 3 trial. Lancet. 2016;388(10056):2128-2141. doi:10.1016/S0140-6736(16)31322-8

84. Busse WW, Bleecker ER, Fitzgerald JM, et al. Long-term safety and efficacy of benralizumab in patients with severe, uncontrolled asthma: 1-year results from the BORA phase 3 extension trial. Lancet Respir Med. 2019;7(1):46-59. doi:10.1016/S2213-2600(18)30406-5

85. Nair P, Wenzel S, Rabe KF, et al. Oral glucocorticoid-sparing effect of benralizumab in severe asthma. $N$ Engl J Med. 2017;376 (25):2448-2458. doi:10.1056/NEJMoa1703501

86. Santini G, Mores N, Malerba M, et al. Dupilumab for the treatment of asthma. Expert Opin Investig Drugs. 2017;26(3):357-366. doi:10.1080/13543784.2017.1282458

87. Food and Drug Administration. Dupilumab prescribing information. [homepage on the Internet]. Available from: https://www.accessdata. fda.gov/drugsatfda_docs/label/2019/761055s014lbl.pdf. Accessed February 22, 2021.

88. European Medicines Agency. Dupilumab summary of product characteristics. [homepage on the Internet]. Available from: https://www. ema.europa.eu/en/documents/product-information/dupixent-eparproduct-information_en.pdf. Accessed February 22, 2021.

89. Wenzel S, Castro M, Corren J, et al. Dupilumab efficacy and safety in adults with uncontrolled persistent asthma despite use of medium-tohigh-dose inhaled corticosteroids plus a long-acting $\beta 2$ agonist: a randomised double-blind placebo-controlled pivotal phase $2 \mathrm{~b}$ doseranging trial. Lancet. 2016;388(10039):31-44. doi:10.1016/S01406736(16)30307-5

90. Busse WW, Maspero JF, Rabe KF, et al. Liberty asthma QUEST: phase 3 randomized, double-blind, placebo-controlled, parallel-group study to evaluate dupilumab efficacy/safety in patients with uncontrolled, moderate-to-severe asthma. Adv Ther. 2018;35(5):737-748. doi:10.1007/s12325-018-0702-4

91. Rabe KF, Nair P, Brusselle G, et al. Efficacy and safety of dupilumab in glucocorticoid-dependent severe asthma. N Engl J Med. 2018;378 (26):2475-2485. doi:10.1056/NEJMoa1804093

92. Castro M, Corren J, Pavord ID, et al. Dupilumab efficacy and safety in moderate-to-severe uncontrolled asthma. $N$ Engl J Med. 2018;378 (26):2486-2496. doi:10.1056/NEJMoa1804092

93. Maspero J, Fitzgerald M, Pavord I, et al. Dupilumab reduces severe exacerbation rate and improves lung function in adolescent patients with uncontrolled, moderate-to-severe asthma: from the Liberty Asthma Quest Study. Chest. 2018;154(4 Suppl):25A-27A. doi:10.1016/j.chest.2018.08.022

94. Sanofi. Evaluation of dupilumab in patients with persistent asthma (Liberty asthma quest). [homepage on the Internet]. Available from: https:/clinicaltrials.gov/ct2/show/NCT02414854. NLM identifier: NCT02414854. Accessed February 22, 2021.

95. Sanofi. Evaluation of dupilumab in patients with severe steroid dependent asthma (VENTURE). [homepage on the Internet]. Available from: https://clinicaltrials.gov/ct2/show/NCT02528214. NLM identifier: NCT02528214. Accessed February 22, 2021.

96. Eyerich S, Metz M, Bossios A, et al. New biological treatments for asthma and skin allergies. Allergy. 2020;75(3):546-560. doi:10.1111/ all.14027

97. Chan R, RuiWen Kuo C, Lipworth B, et al. Pragmatic clinical perspective on biologics for severe refractory type 2 asthma. J Allergy Clin Immunol Pract. 2020;8(10):3363-3370. doi:10.1016/ j.jaip.2020.06.048

98. Ortega H, Llanos JP, Lafeuille MH, et al. Effects of systemic corticosteroids on blood eosinophil counts in asthma: real-world data. J Asthma. 2019;56(8):808-815. doi:10.1080/02770903.2018.1502301

99. Mukherjee M, Nair P. Blood or sputum eosinophils to guide asthma therapy? Lancet Respir Med. 2015;3(11):824-825. doi:10.1016/ S2213-2600(15)00419-1 


\section{Publish your work in this journal}

Biologics: Targets and Therapy is an international, peer-reviewed journal focusing on the patho-physiological rationale for and clinical application of Biologic agents in the management of autoimmune diseases, cancers or other pathologies where a molecular target can be identified. This journal is indexed on PubMed Central, CAS, EMBase,
Scopus and the Elsevier Bibliographic databases. The manuscript management system is completely online and includes a very quick and fair peer-review system, which is all easy to use. Visit http://www.dovepress.com/testimonials.php to read real quotes from published authors. 